\title{
Living Standards and Incentives in Transition: The Implications of UI Exhaustion in Hungary
}

\author{
John Micklewright \\ UNICEF \\ International Child Development Centre, \\ Florence \\ Gyula Nagy \\ Budapest University of Economics
}

April 1998

\begin{abstract}
$\underline{\text { Abstract }}$
The single most likely way to leave the unemployment insurance (UI) register in Hungary is not by getting a job but by exhausting entitlement to benefit. Two questions follow. First, what are the implications of the cessation of UI for living standards? Second, does UI exhaustion have much effect on the probability of getting a job through increasing incentives to work? We investigate these issues with a survey of persons exhausting entitlement to UI in Summer 1995, paying special attention to the household circumstances of the unemployed and to the probabilities of claiming and being awarded means-tested assistance benefit.
\end{abstract}

Keywords: Living standards, Incentives, Hungary, Unemployment Insurance

JEL classification: I38, J64, J65

\section{$\underline{\text { Acknowledgements }}$}

The follow-up survey of $\mathrm{UI}$ exhausters used in the paper was financed by the ILO/Japan Project on Employment Policies in Hungary. We are indebted to Martin Godfrey, the co-ordinator of the project, for his support. We thank the National Labour Centre for much assistance with the survey and especially György Lázár and Zsuzsa Sági. A number of local government officials gave us very useful information on the social assistance scheme and Pravin Trivedi commented constructively on our modelling of it. We thank a referee for useful comments. 


\section{INTRODUCTION}

Central and Eastern European governments in the early 1990s introduced limited-duration Unemployment Insurance (UI) as the primary form of income support for the unemployed. Low outflow rates, sometimes coupled with reductions in benefit entitlement periods, resulted in sharp reductions in the coverage by $\mathrm{UI}$ of the unemployed stock. By the end of 1995, the proportion of the registered unemployed receiving UI was 50 percent in Poland, below 40 percent in Hungary and about 25 percent in both Slovakia and Slovenia, compared to figures of around 75-80 percent in 1991 (Boeri and Edwards, 1996, chart 3, Vodopivec, 1996, table 4). In Hungary, the focus of this paper, exhaustion of $\mathrm{UI}$ entitlement has become so frequent that the most common way for an entrant to the UI register to leave it is by running out of entitlement to benefit, rather than by getting a job. Figure 1 shows monthly outflow rates in Hungary from the stock of UI recipients to jobs and to all other destinations, among which exhaustion of entitlement overwhelmingly dominates. On average only about 5 percent of the stock of $\mathrm{UI}$ recipients left the register each month to get a job in 1994-96, while the total outflow rate was 15-20 percent. The diagram also shows the increasing importance of exhaustion - there is a growing gap between the total outflow rate and the re-employment rate.

Two questions follow: (i) what are the implications of finishing $\mathrm{UI}$ for living standards, and (ii) do these changes in living standards have much effect, via increasing incentives, on the probability of getting a job? These questions have not been adequately addressed in Central and Eastern Europe. In attempting to answer them for Hungary, we consider two related aspects of the debate on unemployment benefits that have seen little attention in existing work on the region. First, we analyse the situation of unemployed individuals within their households. On the one hand, the household circumstances of the unemployed are of obvious importance to their living standards; and on the other, all but the simplest model of job search accords a role in the determination of behaviour to income other than the unemployed individual's benefits and prospective wages. The high incidence of dual earner households pre-reform and the tradition of generous family benefits in the region may imply that the household circumstances of the unemployed matter in Central and Eastern Europe in a way that differs from elsewhere.

Second, we investigate the social assistance scheme that provides support to many persons exhausting UI. As in several other Central and Eastern European countries, social assistance is now received in Hungary by more registered unemployed persons than is UI. The Hungarian scheme shares key features with those in other countries in the region. It is a crude scheme with a simple per capita 
household income test and no tapering of benefit level with rising income. And it is administered and part-financed by local government councils; many have very small populations and little capability in this area of work. The combination of substantial decentralisation and a lack of prior experience at any level of government of providing means-tested benefit of "last-resort" implies that the investigation of social assistance is a priority in research on social safety nets in the region.

Our research is based on a cohort of men and women entering the UI register, coupled with data from a follow-up survey of those cohort members who exhausted $\mathrm{UI}$ entitlement. Exhaustion of $\mathrm{UI}$ is so frequent in Central and Eastern Europe than an investigation of behaviour of the unemployed restricted only to UI register data, as is common in North American research (for example, Meyer, 1990) would miss half the picture. Section 2 summarises what happens to persons who exhaust UI, together with their household circumstances. A model of claims to and awards of social assistance is estimated in Section 3 and we test three hypotheses concerning local variation in the operation of the scheme. Section 4 investigates household living standards (proxied by current income) following UI exhaustion in relation to those while on UI. Section 5 analyses the probability of leaving unemployment to get a job, focusing on the effects of the social assistance system and using both parametric and non-parametric methods. Section 6 concludes.

\section{UI REGISTER DATA AND THE EXHAUSTER SURVEY}

Our research is based on persons in the March and April 1994 inflow to the UI register who had a continuous or near continuous (43-47 months) employment history in the four years prior to claim, resulting respectively in 12 and 11 months entitlement to Ul. This cohort of 28,600 individuals made up two-thirds of the full inflow in the two months concerned (the remaining one third had shorter employment histories resulting in 3-10 months of entitlement). Just under a half of the cohort exhausted UI entitlement. At this point, the individuals concerned are by definition lost from the UI register and what happens to them is unknown.

Our follow-up survey was a random sub-sample of slightly more than a third of these exhausters. Interviews were conducted in their homes with a total of 4,661 individuals, which represented a response rate of nearly 90 percent. $^{1}$ While less rich than household surveys of the unemployed that have been used in some OECD countries (e.g. Narendranathan et al, 1984), the follow-up survey greatly extends

1 The main reason for non-response was inability to find sampled individuals even after a second visit (Micklewright and Nagy, 1996). The sampling fractions of claimants in the 11 and 12 month entitlement groups differed and we apply weights to compensate for this in the descriptive analysis. 
what can be said about living standards and incentives based on UI register data alone.

Interviews were conducted 3 to 4 months after UI exhaustion. Respondents were asked their labour market status in each fortnight since exhaustion, and additionally to report the precise date that a job was first found (excluding casual work). The outcome of any claim to social assistance was recorded. We also collected information on household composition and labour force status of other members of the household, together with the current earnings, if any, of the respondent and spouse. Besides UI previously paid and the past earnings used to determine those payments, the UI register provided details of each claimant's age, educational level, and reason for entry to unemployment. (No information on household characteristics is recorded in the UI register.)

Figure 2 shows survivor functions for both the 11 and 12 month entitlement groups in the inflow cohort. Prior to exhaustion we are looking at survival in the UI register against the "risk" of exit for any reason (e.g. job, training scheme, pension, disqualification). Following exhaustion we treat as remaining in the "base" state (and hence still at risk) individuals who report in the period concerned that they were in any of the categories (i) casual work, (ii) looked for a job but could not find one, (iii) did not look for a job or were not able to work. ${ }^{2}$ Spells of individuals exhausting UI entitlement but who were not included in the follow-up survey are treated as censored at the point of exhaustion. The survivor functions dip sharply following exhaustion and in the case of the 12 month entitlement group there is a similar dip at 6 months, when eligibility for a variety of exits from UI begins, notably early retirement (and labour market programmes). These dips aside, the slopes of the survivor functions appear reasonably similar before and after exhaustion.

Table 1 shows what happens immediately after $\mathrm{UI}$ exhaustion and at the three month point. The dips in the survivor functions at the exhaustion points are reflected in the 6 percent of the sample already in a job in the first fortnight and the 7 percent exiting to receipt of pension or other benefit scheme and, in a few cases, labour market programmes. At the three month point, 1 in 6 of the sample were in employment, and of the remainder the great majority reported that they were looking for a job, although the proportion not searching is notably higher for women. This does not suggest substantial withdrawal from the labour market. ${ }^{3}$

2 The definition of the base state is designed to maximise comparability of pre- and post-exhaustion status. For example, UI recipients may or may not search and may or may not undertake casual work.

3 The classification of status in the follow-up survey was less accurate than would be obtained with a genuine labour force survey instrument. The use of Employment Office clerks for much of the interviewing may have biased upwards the number of 
The household characteristics of the sample are summarised in Table 2. Much debate about income support for the unemployed in Central and Eastern Europe ignores this issue, which corresponds to an implicit assumption that the unemployed live alone, with neither dependants to provide for nor other household members who can help support living standards. Table 2 shows that UI exhausters living alone are in a small minority (although they may be others in multi-person households who do not share equally in all the resources). A third of all men and well over a half of women have a working spouse. A half of men and two-thirds of women live in a household where at least one person works; the figure for both sexes together, 58 percent, is very similar to that of 55 percent for all long-term ILO/OECD unemployed in Hungary in 1993 given by Förster (1996).

Table 3 shows that among the five Central European countries considered by Förster, Hungary had with Slovakia the lowest proportion of long-term unemployed living in households with an earner and - something that may come as a surprise a situation little different to that in several Northern European countries, notably France and the Netherlands. In the other Central European countries, the presence of an earner is rather more common than in Northern Europe but no more so than in Southern Europe and, in two cases - Greece and Portugal - rather less common.

If we include any form of income, the proportion of respondents in the followup survey living with another adult receiving income is as much as three-quarters for both sexes. Of course, other adults generate costs for the household as well as potential resources but this does not detract from their importance in smoothing income changes at the point of $\mathrm{Ul}$ exhaustion. The same is true of dependent children, present in the households of a half of men and two-thirds of women. Children raise household needs but also have an impact on resources - an important feature of the cash transfer system in Hungary is a relatively generous family allowance system which in 1995 paid benefit to parents of all children of the relevant age (Jarvis and Micklewright, 1995). ${ }^{4}$ (Neither UI nor social assistance benefit levels are related to family circumstances.) The monthly family allowance for two children (the modal number) in 1995 was almost exactly the same as the level of social assistance for the unemployed - about 25 percent of the net average wage.

\section{THE PROBABILITY OF SOCIAL BENEFIT RECEIPT}

respondents reporting search. For the same reason the amount of casual work may be understated.

4 Income-testing for family allowance was introduced in 1996 but about two-thirds of families continue to be eligible and the figure must be even higher for the unemployed given their concentration at the bottom of the income distribution. 
Discussion of social assistance for the unemployed often assumes that receipt following exhaustion of $\mathrm{UI}$ is automatic, implying that limited duration $\mathrm{UI}$ followed by possible assistance benefit can be described as a system of "indefinite" support (Atkinson and Micklewright, 1991). This ignores the test of family or household income and assets that is a condition for receipt of assistance benefits. And even when the existence of that test is recognised, the standard assumption is that entitlement is both claimed by the individual and accurately assessed by the benefit agency. This section models claims and awards of social assistance in Hungary. We test three hypotheses concerning local variation in the scheme's operation, variation which should not be present if local authorities operating the scheme follow rules laid down by central government.

Social assistance for the unemployed in Hungary, known as Social Benefit (SB), pays a flat-rate benefit equal, in 1995, to 6,720 forints per month (about $\$ 45$ ). This level is set to be equal to 80 percent of the minimum old-age pension, and, as we shall see later, is well below the level of most UI payments. Application for benefit can only be made after $\mathrm{UI}$ is exhausted and to qualify the claimant's household must have per capita net income below the SB level. Benefit level is not tapered as income approaches this threshold, implying that total household income (including SB) will fall when the threshold is crossed. This crudeness in the scheme is repeated in other features - there are no additions for dependants and the per capita test of income makes no allowance for economies of scale within the household. Unlike UI, SB is not subject to income tax.

$\mathrm{SB}$ is administered by local government councils. There are over 3,000 of these, three-quarters covering areas with under two thousand inhabitants (Bird et al, 1996). Co-funding by central government is intended to provide required funds but maintain financial discipline: only half of councils' expenditure on social benefit can be re-claimed from central funds. ${ }^{5}$ Smaller councils are ill-equipped to administer a major social assistance scheme and their investigation of claims appears minimal. Documentary evidence of household income reported by claimants is required but in the local council areas we checked, home visits are rarely made on the grounds that this would be intrusive. Recipients must stay registered as unemployed at local employment offices (requiring only a monthly visit in one area we visited and a quarterly visit in another) and the councils are informed if registration lapses, but direct contact between the SB recipient and the local council may be limited to the

5 Councils also receive help from the state budget via block grants. These form the majority of their resources and are based on a variety of indicators of need, but they are not explicitly matched to social assistance demand. 
annual check of income required by law. This picture presents SB as "easy money" (as one council official we spoke to labelled it). Against this, however, there is no official application form and awards must be made formally at a meeting of elected council members. This rather public procedure may discourage take-up.

Just under a half of follow-up survey respondents reported receipt of SB since exhausting $\mathrm{UI}$ - our estimate of the unconditional probability of receiving SB following a spell of UI. Receipt among those still in the base state at interview is shown in Table 4. Nearly 60 percent receive at this point; receipt is slightly more common for men. A quarter have never claimed SB, and about 1 in 7 claimed unsuccessfully (or in a few cases were waiting to have a claim decided).

One view of an income-tested benefit has non-receipt due solely to household income exceeding the income threshold, with some households realising this without having to make a claim. In reality the reasons for non-receipt are more varied, involving take-up costs on the one hand and administration errors on the other (e.g. Blundell et al, 1988, and Duclos, 1995). The latter may be accidental or deliberate the agent administering the scheme might ignore the rules. Given the nature of the Hungarian SB scheme described above, these other factors may play a significant role.

The reasons reported by the individuals in Table 4 for not applying for SB were varied, with excessive income cited in only a third of cases. Nearly 1 in 10 said that the procedure was too complicated. More than a quarter reported not to have applied because they had expected to find a job quickly. This seems a curious response given that over a year had already been spent on UI. But if these responses are truthful, then the re-employment probability may be seen as affecting benefit status rather than causality running only in the opposite direction. Viewed another way, these answers may just indicate very high take up costs for the individuals concerned.

We model the information in Table 4 with equations for the probability of claim and of award:

$$
\begin{array}{ll}
\mathrm{p}(\text { claim }) & =\mathrm{F}(\mathrm{E}(\mathrm{SB}), \text { claiming costs }) \\
\mathrm{p}(\text { award }) & =\mathrm{F} \text { (claimant income, council factors }) .
\end{array}
$$

where $\mathrm{E}(\mathrm{SB})$ is the $\mathrm{SB}$ that the individual expects to receive conditional on his or her circumstances. This equals the individual's subjective probability of an award, multiplied by the fixed SB level. ${ }^{6}$ In an ideal world, this perceived probability would

6 The theoretical model underlying equation (1) assumes that risk-neutral individuals compare an uncertain income in the event of a claim (incomes net of claiming costs 
equal unity when income is above the threshold and zero when below. But reality may depart from this ideal for several reasons. Some households may not know the rules and may apply despite their incomes being too high to qualify, their expected SB being based on an incorrect perception of the actual probability of an award. But even households who know the rules and have incomes above the threshold may have a positive expectation of benefit in excess of their claiming costs and may hence apply, in the hope that local council administration is imperfect or because they intend not to declare some of their income. Finally, as "take-up analysts" (Duclos, 1995) our observation of income is undoubtedly imperfect, so from a practical point of view we cannot base calculations of entitlement on observed income alone.

The actual probability of award, equation (2), depends on the council's observation of the claimant's income (which may be imperfect) together with other factors affecting its decision-making process. We include three variables.

(i) the local employment office area unemployment rate, hypothesised to have a positive impact due to increased council generosity towards their electors in areas where job prospects are poor; ${ }^{7}$

(ii) total income assessable for Personal Income Tax (PIT) per head of population in the claimant's council area in 1994, which we use as a proxy for ability to fund SB and hence of willingness to make awards; $;$ we hypothesise that (conditional on claimant income) poorer councils are less likely to make awards.

in the award and no-award outcomes weighted by their respective perceived probabilities) and a certain income if no claim is made. The SB level is a flat-rate sum; since it displays no variation it can play no part in the empirical modelling, in contrast to the take-up models of Blundell et al (1988) and Duclos (1995).

7 An alternative view, suggested to us by a local council office, is that in areas of high unemployment there is a high demand for various other forms of social assistance, which, in contrast to SB, are funded wholly from councils' own resources. In this situation, there is an incentive for councils to use the SB scheme for the unemployed. On this view, SB may represent "easy money" for councils as well as claimants.

8 A proportion (35 percent in 1995) of PIT revenue is returned to the council area of derivation and although these funds represent only about 10 percent of total local council revenue nationally (Bird et al, 1996) the council area taxable personal income should proxy a number of other sources, including property taxes. (Direct transfers from central government are equalising but do not remove differences.) 
(iii) The local council area population. Our hypothesis is that smaller councils are less able or willing to investigate claims and hence in these areas benefit is more likely to be awarded.

If the system functions according to the rules laid down in the relevant legislation, none of these three variables should have a significant impact (conditional on observed claimant income). If they are significant then this suggests an element of discretion in the scheme that should not be present.

Although subjective and actual probabilities of award may differ, potential claimants may have some awareness of their local council's policy on awards (or their efficiency in determining claims) that helps form their own perceptions of the award probability. Some variables in the award equation should thus be included in the claim equation. Some of these variables may also affect claiming costs. Increased income may raise the stigma attached to receipt of benefit as well as lowering the perceived probability of award. Higher unemployment may lower the disutility of claiming since expected duration on benefit rises. ${ }^{9}$ We enter other variables assumed to have a direct impact on claiming costs and no impact on $\mathrm{E}(\mathrm{SB})$, notably education and the level of the individual's previous $\mathrm{UI}$ benefit (expected to have a similar impact on stigma to that of other household income).

Equations (1) and (2) are estimated together as a bivariate probit model. ${ }^{10}$ Table 5 gives results for men and women separately; the estimated impacts of unemployment and income for men are graphed in Figure 3. The estimated error correlation in the two equations is insignificant for both sexes, but the apparent selfselection effect is rather sensitive to the specification of the equations.

9 In other words, the average monthly claiming cost falls as unemployment rises. 10 Let the propensity to claim and to be awarded benefit be given by $Y_{1}$ and $Y_{2}$ respectively with corresponding binary variables $D_{1}$ and $D_{2}$ indicating an observed claim and award, where:

$Y_{1}=\beta_{1} X_{1}+\varepsilon_{1}$

$Y_{2}=\beta_{2} X_{2}+\varepsilon_{2}$

We observe: $D_{1}=1$ if $Y_{1}>0\left(D_{1}=0\right.$ otherwise $)$

$D_{2}=1$ if $Y_{2}>0$ and $Y_{1}>0$

$D_{2}=0$ if $Y_{2} \leq 0$ and $Y_{1}>0\left(D_{2}\right.$ is not observed if $\left.Y_{1} \leq 0\right)$.

We assume that $\varepsilon_{1}$ and $\varepsilon_{2}$ follow a bivariate normal distribution with means zero, variances unity, and correlation coefficient $\rho$. The log-likelihood of the observed data is maximised with respect to $\boldsymbol{\beta}_{1}, \boldsymbol{\beta}_{2}$, and $\rho$. 
Although strongly significant in both equations, household income appears to affect awards more than claims. ${ }^{11}$ This may imply that administration errors or laxity in adjudicating claims are less important than ignorance of the rules or other influences that weaken the influence of income on claim behaviour. Figure 3 shows that moving from the bottom to the top of the per capita income distribution reduces the award probability for a man by about 0.6 and the claim probability by about 0.35 . The estimated effects for women are somewhat larger, especially for claims.

The hypothesis of no local effects in the determination of awards is rejected, although the results are mixed. In particular, the unemployment rate has a significant, although not particularly well-determined, positive impact for both sexes (well beyond its possible effect on local wage rates and hence any unobserved household income). Figure 3 shows that the range of observed unemployment rates in the 170 employment office areas in the data is associated with a ceteris paribus difference in the probability of receiving an award of about 0.25 . On the other hand, council area taxable income is completely insignificant for both sexes. This is encouraging: there is no evidence that poorer councils are less disposed to make SB awards, given observed claimant income. Council area population, however, has a positive impact for men. A 10 percent rise in population is estimated to increase the award probability by about 1 percent - there is no evidence that smaller councils are more lax and thus more generous. The result could obviously be interpreted in the opposite way - that smaller councils are tougher - but this is not the only possible interpretation. Moreover, the result is not found for women, which complicates the interpretation for men, and in the larger cities there is a mixture of estimated impacts.

The effect of local unemployment on claims is larger and notably better determined than that on awards - a lower disutility of claims re-enforcing any effect coming through the perceived probability of awards. A number of other variables have big effects on claims. For example, women with less than primary education have a probability of claiming that is up to 40 percent points higher than women with primary education; claims are somewhat more likely from single than from married women. In both cases our interpretation is that claiming costs are lower. The

11 Income is only partially observed within the survey and we undertook some imputation to arrive at a total for the household. We observe the net earnings of spouses but not of other household members, for whom we know only the employment status. We imputed earnings for the latter from regressions run on the former. Family allowances were imputed following the rules in force at the time of the survey. Pensions and other social security benefit income were imputed from regressions run on the TARKI Hungarian household panel (we observe their presence in the follow-up survey but not the amount received). 
previous level of $\mathrm{Ul}$ benefit (which of course is not taken into account in the SB income test) has no discernible impact on the claim probability for men but an important and well determined negative impact for women, not much less that that for household income. Our interpretation is that stigma from claiming rises with UI level although it is difficult to think why this should be the case only for women.

These results show that the probability of receipt of social assistance in Hungary is influenced by several factors other than income level, counseling against an overly-simple view of the operation of such schemes. The results also enable us to predict receipt for all the follow-up survey sample and we build on this in the rest of the paper.

\section{LIVING STANDARDS FOLLOWING EXHAUSTION}

Living standards during unemployment can be measured in a number of ways. An obvious possibility is to assess income or expenditure in relation to an absolute poverty line, as in an assessment of poverty in Hungary by the World Bank (1996). The authors adopt as a poverty threshold the minimum pension level, argued to be sufficiently low to identify "the very poorest individuals" (p.16). This is well above the SB level and the setting of the latter clearly reflects a concern with costs and incentives. Were the greater subsistence needs of an active person to be recognized, SB would be the higher of the two levels.

Measuring living standards by equivalised annual expenditure, 5 percent of all households in the 1993 budget survey were found to be beneath the minimum pension level (World Bank, 1996, Table 1.7). However, poverty in households with an unemployed head, on this yardstick, was about 15 percent if some form of unemployment benefit was received and as high as 40 percent if there were no benefits. On the other hand, these figures fall to 5 and 15 percent in households containing an unemployed person but with an employed head. These results show the generally disadvantaged position of many unemployed, particularly those without benefits, but also demonstrate that living standards will vary notably with the labour force status of other household members.

Our concern is less with the absolute level of living standards of the unemployed than with how these change at exhaustion of UI. There may be smoothing of consumption across this event but we cannot observe this with the 
available data and instead proxy changes in living standards by changes in monthly income. ${ }^{12}$ We consider two income ratios:

i) SB / last net UI payment;

ii) net household income following exhaustion / net household income when the individual last received UI.

The first ratio focuses on the individual's benefits while the second incorporates other sources of household income.

Tables 6 gives descriptive statistics on these ratios and is restricted to those in the "base state" at interview (still unemployed). It shows that SB, if received, replaces on average two-thirds of $\mathrm{UI}$ for men and three-quarters for women - a significant drop in benefit income. In 1 in 10 cases there is a fall of less than 20 percent while for a similar number benefit income falls by a half. The bottom part of the table shows how the picture is modified by other household income. Where SB is not received, household income on average falls by about 40 percent when UI finishes (somewhat more for men and less for women). Other sources of income clearly play an important role in supporting living standards and the same is true where SB is received: the mean ratio of household incomes before and after exhaustion is over 80 percent for men and nearly 90 percent for women. The figures vary substantially with household circumstances. For example, when no SB is received a woman whose husband does not work faces an average income drop of 50 percent compared to 25 percent for women with employed husbands. Replacement rates are some 5 to 10 percentage points higher on average where there are dependent children. This emphasises the role of family allowances in cushioning income changes resulting from the unemployment benefit system (although the data may also reflect other differences between households with and without children). ${ }^{13}$

12 Studies using data on consumption changes during unemployment are rare. An exception is that by Gruber (1997) who shows how UI supports households' consumption in the US. See also Browning and Crossley (1996).

13 The importance of the household in reducing relative income changes should not be confused with its impact on the absolute level of living standards of the unemployed. While other household members could reduce the probability of being below a poverty threshold, for example where they are employed, they could also increase it. For example, children may "bring" family allowance to the household but overall their presence may typically reduce total equivalised income. Although family allowance dampens down income changes following benefit and labour market transitions, a household may still be worse-off in absolute terms as the result of its children. 
Both SB and other income in the household clearly provide an important cushion to the impact of ending UI entitlement. In the next section we try to deduce the impact on individual behaviour of these changes in household income.

\section{INCENTIVES TO RETURN TO WORK}

How does exhaustion of $\mathrm{UI}$ affect job-finding behaviour? The analysis of income ratios suggests that for some individuals the impact will be limited - some incomes fall by only a small amount and for many there are other sources of income providing substantial support. But it would be misleading to view the income changes brought on by exhaustion of $\mathrm{UI}$ and possible transfer to $\mathrm{SB}$ as being necessarily equal in effect to those of the same magnitude resulting from, say, a fall in the level of a continuing benefit. SB is paid by a different agency to that administering $\mathrm{UI}$ and eligibility is determined under a different set of rules; Section 3 argues that any switch to the new benefit involves uncertainty and transaction costs and behaviour around the point of exhaustion can be expected to reflect this.

The mean percentage changes in household incomes shown in Table 6 differ by some 25 points between those with and without SB - a big difference. Figure 4 focuses on this, showing how the job exit hazard changes around the UI exhaustion point, distinguishing between persons predicted to have low and high probabilities of getting assistance benefit. Hazards are estimated non-parametrically using oneweek intervals. Estimation until the point of exhaustion uses the full inflow cohort from which the exhauster survey was drawn, conditional on survival in the UI register to within four months of the exhaustion point. Spells ending in exits to states other than a job are treated as censored at the point of exit as are those spells lasting until exhaustion that were not included in the follow-up survey.

Figure 4 is restricted to those in the top and bottom thirds of the distribution of predicted probabilities of SB entitlement. These probabilities are based on a probit estimated for those in the follow-up survey who at interview were either (i) receiving $\mathrm{SB}$, or (ii) reported being refused benefit due to the level of household income or not claiming at all on grounds of income level. We thus try to restrict estimation to those individuals where entitlement definitely existed or where it appears not to have done so. In order to inspect the hazards before as well as after the exhaustion point, the model is estimated only with variables available from the UI register or which refer to the local area, i.e. data available for the whole inflow cohort rather than just for the follow-up survey sample. ${ }^{14}$

14 Although this model of "entitlement" reflects determinants of claim as well as award, it tries to restrict the former to cases where $E(S B)$ is perceived to be low on 
It is tempting to compare directly the levels of the hazards for those with high and low predicted SB probabilities, noting for example the different heights of any spikes around the UI exhaustion point. However, this would not be a comparison that held other things equal. Individuals with high SB probability may have other characteristics that hold their employment hazard down, and the level of any observed spike will reflect this. It is the comparison of the changes in the hazards that is more appropriate. Does the low SB probability group experience a larger change in the hazard around the exhaustion point than the high probability group?

The hazard for men with low SB probability almost doubles in the last week of $\mathrm{UI}$ entitlement, having only risen slightly in the previous four months. This is nothing compared to the jump in the next week, the first following exhaustion of UI, when there is a six-fold increase in the hazard over the average value in the 6 weeks prior to exhaustion (leaving out the last week from this calculation). ${ }^{15}$ But the high SB probability group experiences an even bigger surge, with an eight-fold increase between the same two periods. These huge rises last for just one week - the hazards then fall back in the subsequent three weeks for the low probability group to a level similar to that in the last week of UI, namely higher than earlier, and thereafter oscillates at levels similar to those in the months preceding exhaustion. ${ }^{16}$ The pattern of results for women is similar. The hazards for both low and high SB probability groups in the first week following exhaustion are five times larger than those in the six weeks preceding exhaustion (excluding the last week). Compared to a base level in earlier months, the rise for the low probability group is, however, somewhat larger.

The evidence in Figure 4 does not suggest that job search behaviour around the time of UI exhaustion is strongly related to the probability of entitlement to SB. There certainly appear to be persons who time their return to work to coincide with the point of $\mathrm{UI}$ exhaustion, but this behaviour does not seem to be very different for those with high and low probabilities of SB. Further investigation failed to reveal any distinguishing feature of this group in terms of observable characteristics. It is also important to keep the size of this group in perspective. If we take all job exits by the cohort from time of inflow to UI until the follow-up survey date (weighting the post-

account of the level of household income. A model that included all non-recipients would produce predictions that reflected in addition the impact of claiming costs, which we certainly would not want for the purpose in hand.

15 The 95 percent confidence interval for the hazard in the last week of $\mathrm{UI}$ is from 0.0033 to 0.0058 ; that in the following week is from 0.0104 to 0.0174 .

16 The greater variability of the hazard following exhaustion is due to the smaller sample from this point, the follow-up survey not covering all exhausters in the cohort. 
exhaustion exits to take account of the sampling from that point), the "first week post-UI" exits account for only 8 percent of the total. ${ }^{17}$

We now estimate a parametric model of duration in the "base state" following $\mathrm{UI}$ exhaustion. The job-exit hazard is specified as a logit function of (i) observable characteristics and (ii) time in the state, with all exits to states other than employment treated as censored. Parameters are estimated from a discrete-time model of weeks in the base state, following the procedure outlined in Jenkins (1995). We condition on survival beyond the first week following exhaustion of UI. This means that we do not attempt to model the determinants of the spikes in Figure 4. Our conclusion is that unobserved heterogeneity is generating this phenomenon and the easiest solution is to condition on survival past the risk of exit at this point. ${ }^{18}$

Financial incentives to return to work are captured by variables representing $E(S B)$, the mean of the wage offer distribution, and other household income. In the six weeks following exhaustion, $\mathrm{E}(\mathrm{SB})$ is taken as the probability of an award predicted from the award equation results in Table 5 multiplied by the SB level (6,720 forints); thereafter, the variable is set to the SB level if the data collected at interview show that an award was actually made and to zero otherwise. Local councils awarding SB meet monthly and we assume that it takes six weeks for the process of claim and award to work through. ${ }^{19}$ The mean of the wage offer distribution is approximated by the fitted values of a regression run on new job wages for those exiting to employment, in which explanatory variables include the previous earnings on which $\mathrm{UI}$ was based and a number of personal characteristics. The other household income variable contains the same items as entered the calculations of income ratios in Table 6. Controls are included for age, education, marital status, circumstances of entering unemployment, and the strength of the local labour market. The base-line hazard is modelled by a series of dummy variables for each week until week 20.

Results are given in Table 7 (the coefficients of the base-line dummies are not reported). The first two columns give the results of a specification including the controls only. These differ notably between the sexes. Age has a strong and well

17 The spikes in the hazard occur in the week that our data source switches from administrative records to interview survey. Having investigated the recording process of the $\mathrm{UI}$ register, we do not believe this switch affects the total number of recorded job exits around the Ul exhaustion point. It is possible that recall error in the followup survey results in rather too many exits being recorded in the first week in relation to later weeks but we think this a minor problem at most.

18 In fact the results are not particularly sensitive to this selection.

19 Among those still unemployed after six weeks, 62 percent of those who do not get a job by the date of interview receive SB at some time and 33 percent of those who do find work. 
determined negative effect for men, a 10 percent increase in age leading to a fall in the hazard of about 8 percent. ${ }^{20}$ But there is no discernible impact for women. Marital status has no effect for women while a married man has a hazard 1.5 times that of a single man. Increased education has an important positive effect for both sexes. Hazards are lower where there is a higher rate of local unemployment, although the effect is neither very well determined nor large.

The last two columns include the three income variables described above. The coefficients on the SB variable and the predicted wage have the signs one would expect and are significant, the former being particularly well determined for both sexes. Other household income, on the other hand, is completely insignificant. This result is surprising and the apparent implication is that individuals base behaviour on benefit and wages only, as in the simplest search model. Of course, other household income affects the probability of receiving SB, hence influencing the hazard indirectly, and the correlation between any SB variable and other household income hinders the identification of their separate impacts. We experimented with various further specifications. For example, we removed the switch in the value of the $E(S B)$ after 6 weeks, making it equal throughout to the predicted probability of award multiplied by the SB level, dropping at the same time the other household income variable; the estimated coefficients were very similar (although the standard errors doubled). The inclusion of the income variables changes the impact of some of the controls, notably that of the local unemployment rate, which changes sign. The apparent implication is that the negative impact on the hazard of higher local unemployment in the model with no income variables reflects only an indirect effect through an increased probability of an SB award, although it may be that we are simply unable to identify the separate effects adequately.

The elasticity of the hazard with respect to $E(S B)$ implied by the results in Table 7 is about -0.7 for both sexes. This represents a rather modest benefit effect and one not out of line with that found in some OECD countries (for example, Narendranathan et al, 1985). It is also seems in line with our non-parametric results, which show big changes in the hazard at UI exhaustion for some individuals but do not suggest that this has much to do with the probability of going on to receive SB. Finally, it echoes the low benefit elasticities suggested by our earlier work that used a quasi-experimental design to look at the impact of a change in UI rules on the behaviour of UI recipients (Micklewright and Nagy, 1995).

20 With the logit functional form for the hazard, $h$, elasticities are given by $(1-h) \beta$ for variables in logs and (1-h) $\beta x$ if in levels. In our calculations in the text we take $h$ as very small and the mean value of $x$. 


\section{CONCLUSIONS}

Exhausting entitlement is the most common way of leaving the UI register in Hungary. Our analysis of a follow-up survey of exhausters has shed light on what happens next and hence on a number of aspects of living standards of the unemployed, labour market flows and the design of policy. (The similarities across much of Central and Eastern Europe in the nature of labour markets and social safety nets suggests that the findings may also be relevant for other countries in the region.)

- Means-tested assistance benefit provides income support to about a half of all exhausters in Hungary and, in common with several other Central and Eastern European countries, there are more unemployed recipients of assistance benefit than there are of UI. A model of claims and awards suggests that claiming costs may be important and that there is some variation in local councils' treatment of claims that is unrelated to claimants' income levels. Further investigations of this type are needed in other transition economies given a region-wide move to increased decentralisation of social protection policy. A positive finding in the Hungarian case is the absence of any association of the award probability with the local council resource base.

- $\quad$ The impact of UI exhaustion on living standards (proxied by income) depends notably on household circumstances, which have often been ignored in analysis of the unemployed in transition economies. The presence of other earners is a key issue and we showed how Hungary compares in this respect with a range of other European countries. A half of the married men in our sample had a spouse who did not work but only a quarter of the married women; a half of all the men and two-thirds of the women had dependent children.

- $\quad$ One group of claimants appears to time the return to work to coincide with the exhaustion of UI entitlement. Changes in benefit duration or levels would be a crude tool with which to change incentives for this group and a more appropriate policy response would be to try to identify these claimants early on in their UI spells and administer their claims in such a way as to encourgage earlier exits. 
- $\quad$ The speed of return to work both before and after UI exhaustion does not appear to be very strongly related to the probability of entitlement to social assistance - the bulk of the Hungarian unemployed appear rather inelastic to changes in income levels. The reasons for this are a matter for interpretation. One approach would point to the existence of opportunities for working in the black economy while receiving support from the state. A more charitable explanation would centre on the individuals' lack of command over full-time job offers paying reasonable wages. 


\section{$\underline{\text { References }}$}

Atkinson, A B and Micklewright J (1991), "Unemployment Compensation and Labor Market Transitions", Journal of Economic Literature, 29: 1679-1727.

Bird, R, Wallich, C and Péteri, G (1996), "Financing Local Government in Hungary", in Bird, R, Ebel, R and Wallich, C, (eds.) Decentralization of the Socialist State: Intergovernmental Finance in Transition Economies, Averbury, Aldershot.

Blundell, R, Fry, V and Walker, I (1988), "Modelling the Take-up of Means-Tested Benefits: The Case of Housing Benefits in the United Kingdom", Economic Journal, 98: 58-74.

Boeri, T and Edwards S, (1996) "Long-term Unemployment and Short-Term Unemployment Benefits: The Changing Nature of Non-Employment Subsidies in Central and Eastern Europe", OECD, mimeo.

Browning, M and Crossley T, (1996), "Unemployment Insurance Benefit Levels and Consumption Changes", McMaster University, mimeo.

Duclos, J-Y (1995), "Modelling the Take-Up of State Support", Journal of Public Economics, 58: 391-415.

Förster, M (1996), "The Household Situation of the Unemployed", Luxembourg Employment Study, CEPS/INSTEAD, Luxembourg.

Gruber, J (1997), "The Consumption Smoothing Benefits of Unemployment Insurance", American Economic Review, 87: 192-207.

Jarvis, J and Micklewright, J (1995), "The Targeting of Family Allowances in Hungary", in Van de Walle, D and Nead, K (eds.), Public Spending and the Poor: Theory and Evidence, John Hopkins University Press.

Jenkins, S (1995), "Easy Estimation Methods for Discrete-Time Duration Models", Oxford Bulletin of Economics and Statistics, 57: 129-38.

Meyer, B (1990) "Unemployment Insurance and Unemployment Spells", Econometrica, 58: 757-82.

Micklewright, J and Nagy, Gy (1995) "Unemployment Insurance and Incentives in Hungary: Preliminary Evidence", CEPR Discussion Paper 1118, and in Newbery, D (editor), Tax and Benefit Reform in Central and Eastern Europe, CEPR, London. 
Micklewright, J and Nagy, Gy (1996) "A Follow-Up Survey of Unemployment Insurance Exhausters in Hungary", European University Institute Working Paper in Economics 96/8.

Narendranathan, W, Nickell S and Stern J (1985) "Unemployment Benefits Revisited", Economic Journal, 95: 307-329.

Vodopivec, M (1996) "Transition from Cash Benefits to Work: The Case of Slovenia", OECD, mimeo.

The World Bank (1996), Hungary: Poverty and Social Transfers, Washington D.C. 


\section{TABLES}

Table 1: Activity of UI Exhausters 1 Week and 3 Months after Exhaustion

\begin{tabular}{l|rrr|rrr|}
\hline & \multicolumn{3}{|c|}{ 1 week after exhaustion } & \multicolumn{3}{c|}{3 months after exhaustion } \\
\cline { 2 - 7 } & $\begin{array}{c}\text { Men } \\
\%\end{array}$ & $\begin{array}{c}\text { Women } \\
\%\end{array}$ & $\begin{array}{c}\text { Total } \\
\%\end{array}$ & $\begin{array}{c}\text { Men } \\
\%\end{array}$ & $\begin{array}{c}\text { Women } \\
\%\end{array}$ & $\begin{array}{r}\text { Tota } \\
\% l\end{array}$ \\
\hline Base state: & & & & & & \\
Searching for a job & 70.5 & 68.3 & 69.4 & 54.1 & 54.9 & 54.5 \\
Not searching for a job & 7.6 & 14.0 & 10.8 & 6.7 & 13.3 & 10.0 \\
Casual work + search & 8.7 & 3.2 & 6.0 & 8.2 & 2.4 & 5.3 \\
Casual work, no search & 1.0 & 0.7 & 0.9 & 1.2 & 0.7 & 0.9 \\
$\quad$ Exits: & & & & & & \\
Employment & 7.0 & 5.7 & 6.4 & 20.9 & 16.8 & 18.8 \\
Training / Public works & 0.5 & 0.5 & 0.5 & 2.3 & 1.2 & 0.8 \\
Child care / Pension & 4.0 & 6.6 & 5.3 & 5.8 & 9.3 & 7.6 \\
Other & 0.6 & 0.9 & 0.8 & 0.8 & 1.3 & 1.1 \\
Total & 100.0 & 100.0 & 100.0 & 100.0 & 100.0 & 100.0
\end{tabular}

Note: Percentages are based on weighted data.

Table 2: Household Characteristics of UI Exhausters

\begin{tabular}{l|c|c|}
\hline & $\begin{array}{c}\text { Men } \\
\%\end{array}$ & $\begin{array}{c}\text { Women } \\
\%\end{array}$ \\
\hline Living alone & 11.3 & 4.0 \\
Single & 31.2 & 22.1 \\
Married, spouse works & 34.1 & 57.9 \\
Married, spouse does not work & 34.7 & 19.0 \\
Other working adult, not including & 19.3 & 16.0 \\
$\quad$ spouse & 47.5 & 67.6 \\
Any working adult, including spouse & 74.9 & 78.0 \\
Any adult in household with income & 47.9 & 68.3 \\
Dependent child & & \\
Average household size & 3.2 & 3.4
\end{tabular}

Note: Percentages are based on weighted data. 
Table 3: Percent of long-term unemployed living in a household with at least one employed member

Northern Europe

UK

Ireland

Belgium

Germany

France

Netherlands
34.6

47.4

48.0

49.1

55.3

56.0
Central Europe

Slovakia

Hungary

Czech

Poland

Slovenia
51.9

54.8

60.8

63.5

68.6

Southern Europe

Spain

Italy

Greece

Portugal
64.7

67.2

70.9

83.2

Note: Data for 1993/94 from Labour Force Surveys (Förster, 1996)

Table 4: Social Benefit Receipt if in "base" state at interview

\begin{tabular}{l|rrrrrr|}
\hline & Men & Women & Search & $\begin{array}{c}\text { No } \\
\text { search } \\
\%\end{array}$ & $\begin{array}{c}\text { Casual } \\
\text { work } \\
\%\end{array}$ & Total \\
& $\%$ & $\%$ & $\%$ & \multicolumn{1}{c}{$\%$} & \multicolumn{1}{c}{$\%$} \\
\hline SB in receipt & 61.1 & 56.9 & 62.3 & 41.9 & 26.6 & 59.0 \\
Received earlier & 2.8 & 1.9 & 2.1 & 3.9 & 3.4 & 2.4 \\
Unsuccessful claim & 12.4 & 15.6 & 13.7 & 15.6 & 19.5 & 14.0 \\
Has not claimed & 23.8 & 25.5 & 22.0 & 38.6 & 50.6 & 24.7 \\
Total & 100.0 & 100.0 & 100.0 & 100.0 & 100.0 & 100.0
\end{tabular}

Note: The "base" state are the first four rows in Table 1. Percentages based on weighted data. 
Table 5: Bivariate Probit Model of SB Claim and Receipt

\begin{tabular}{|c|c|c|c|c|}
\hline & \multicolumn{2}{|c|}{ Men } & \multicolumn{2}{|c|}{ Women } \\
\hline & Claim & Award & Claim & Award \\
\hline Constant & $\begin{array}{l}-0.176 \\
(0.7)\end{array}$ & $\begin{array}{l}-0.025 \\
(0.05)\end{array}$ & $\begin{array}{l}1.825 \\
(6.7)\end{array}$ & $\begin{array}{l}1.505 \\
(3.8)\end{array}$ \\
\hline Income per capita (000s Forints) & $\begin{array}{l}-0.068 \\
(6.2)\end{array}$ & $\begin{array}{l}-0.144 \\
(5.7)\end{array}$ & $\begin{array}{l}-0.099 \\
(8.7)\end{array}$ & $\begin{array}{l}-0.175 \\
(9.7)\end{array}$ \\
\hline Previous UI (000s Forints) & $\begin{array}{l}-0.013 \\
(0.8)\end{array}$ & & $\begin{array}{l}-0.084 \\
(4.7)\end{array}$ & \\
\hline Married & $\begin{array}{l}-0.100 \\
(1.3)\end{array}$ & & $\begin{array}{l}-0.269 \\
(2.7)\end{array}$ & \\
\hline Incomplete primary education & $\begin{array}{l}0.396 \\
(2.2)\end{array}$ & & $\begin{array}{l}0.952 \\
(3.0)\end{array}$ & \\
\hline Vocational school & $\begin{array}{l}-0.190 \\
(2.2)\end{array}$ & & $\begin{array}{l}-0.166 \\
(1.8)\end{array}$ & \\
\hline Vocational secondary school & $\begin{array}{l}-0.319 \\
(2.3)\end{array}$ & & $\begin{array}{l}-0.393 \\
(3.5)\end{array}$ & \\
\hline General secondary school & $\begin{array}{l}-0.414 \\
(2.2)\end{array}$ & & $\begin{array}{l}-0.228 \\
(1.8)\end{array}$ & \\
\hline Higher education & $\begin{array}{l}-0.502 \\
(2.2)\end{array}$ & & $\begin{array}{l}-0.807 \\
(1.9)\end{array}$ & \\
\hline Age & $\begin{array}{l}0.009 \\
(2.3)\end{array}$ & & $\begin{array}{l}-0.005 \\
(1.2)\end{array}$ & \\
\hline Local unemployment rate (\%) & $\begin{array}{l}0.103 \\
(9.7)\end{array}$ & $\begin{array}{l}0.069 \\
(2.6)\end{array}$ & $\begin{array}{l}0.064 \\
(5.5)\end{array}$ & $\begin{array}{l}0.040 \\
(2.4)\end{array}$ \\
\hline Budapest dummy & $\begin{array}{l}0.510 \\
(3.7)\end{array}$ & $\begin{array}{l}0.318 \\
(1.1)\end{array}$ & $\begin{array}{l}0.315 \\
(2.5)\end{array}$ & $\begin{array}{l}0.488 \\
(1.9)\end{array}$ \\
\hline Other big city dummy & & $\begin{array}{l}-0.497 \\
(2.3)\end{array}$ & & $\begin{array}{l}-0.218 \\
(1.0)\end{array}$ \\
\hline Population of local council area (log) & & $\begin{array}{l}0.124 \\
(2.6)\end{array}$ & & $\begin{array}{l}-0.025 \\
(0.5)\end{array}$ \\
\hline $\begin{array}{l}\text { Taxable personal income in local council area } \\
\text { (per capita, 000 Forints) }\end{array}$ & & $\begin{array}{l}-0.001 \\
(0.5)\end{array}$ & & $\begin{array}{l}-0.002 \\
(0.1)\end{array}$ \\
\hline Error correlation $(\rho)$ & $\begin{array}{l}-0 . \\
(0 .\end{array}$ & & $\begin{array}{l}-0 \\
(0\end{array}$ & \\
\hline Log-likelihood & -122 & & & 54.09 \\
\hline $\begin{array}{l}\text { Sample size } \\
\text { Number of claimants } \\
\text { Number of recipients }\end{array}$ & $\begin{array}{r}15 \\
11 \\
9\end{array}$ & & & $\begin{array}{l}525 \\
105 \\
367\end{array}$ \\
\hline
\end{tabular}

Notes: T-statistics in parentheses. The sample used in estimation is those individuals who at interview are in casual work, searching for a job, or who are inactive. 
Table 6: Income changes on exhausting UI

\begin{tabular}{|c|c|c|c|c|}
\hline & \multicolumn{2}{|c|}{ Men } & \multicolumn{2}{|c|}{ Women } \\
\hline & No SB & SB & no SB & SB \\
\hline & \multicolumn{4}{|c|}{$S B / U I \%$} \\
\hline Bottom Decile & & 47.6 & & 54.5 \\
\hline Top Decile & & 83.1 & & 84.4 \\
\hline \multirow[t]{2}{*}{ Mean } & & 68.3 & & 77.7 \\
\hline & \multicolumn{4}{|c|}{$\begin{array}{l}\text { Ratio of post- to pre-exhaustion householo } \\
\text { income, } \%\end{array}$} \\
\hline Mean: & & & & \\
\hline All individuals & 57.5 & 82.2 & 66.1 & 89.0 \\
\hline Married, spouse not working & 52.0 & 81.8 & 48.8 & 87.2 \\
\hline Married, spouse working & 67.0 & 86.4 & 73.0 & 92.9 \\
\hline No dependent children & 53.9 & 80.1 & 62.1 & 84.3 \\
\hline Dependent children & 63.0 & 84.8 & 68.6 & 91.0 \\
\hline Sample size & 602 & 944 & 658 & 867 \\
\hline
\end{tabular}

Note: Percentages are based on weighted data. 
Table 7: Discrete-time duration model of the post-Ul exhaustion job exit hazard (logit functional form)

\begin{tabular}{|c|c|c|c|c|}
\hline & \multicolumn{2}{|c|}{ Controls only } & \multicolumn{2}{|c|}{ Full model } \\
\hline & Men & Women & Men & Women \\
\hline Age (log) & -0.804 & -0.025 & -0.953 & -0.370 \\
\hline Incomplete primary education & $\begin{array}{l}-1.157 \\
(3.0)\end{array}$ & $\begin{array}{l}-0.489 \\
(1.3)\end{array}$ & $\begin{array}{l}-1.008 \\
(2.6)\end{array}$ & $\begin{array}{l}-0.048 \\
(0.1)\end{array}$ \\
\hline Vocational school & $\begin{array}{l}0.291 \\
(2.6)\end{array}$ & $\begin{array}{l}0.246 \\
(1.8)\end{array}$ & $\begin{array}{l}0.147 \\
(1.3)\end{array}$ & $\begin{array}{l}0.236 \\
(1.8)\end{array}$ \\
\hline Vocational secondary school & $\begin{array}{l}0.702 \\
(4.9)\end{array}$ & $\begin{array}{l}0.516 \\
(3.5)\end{array}$ & $\begin{array}{c}0.276 \\
(1.6)\end{array}$ & $\begin{array}{l}0.027 \\
(0.1)\end{array}$ \\
\hline General secondary school & $\begin{array}{c}0.427 \\
(1.7)\end{array}$ & $\begin{array}{l}0.626 \\
(4.2)\end{array}$ & $\begin{array}{l}0.601 \\
(2.3)\end{array}$ & $\begin{array}{l}0.201 \\
(0.9)\end{array}$ \\
\hline Higher education & $\begin{array}{l}0.661 \\
(2.6)\end{array}$ & $\begin{array}{l}1.071 \\
(3.6)\end{array}$ & $\begin{array}{l}-1.191 \\
(2.2)\end{array}$ & $\begin{array}{l}0.602 \\
(1.8)\end{array}$ \\
\hline Job leaver & $\begin{array}{l}-0.301 \\
(1.7)\end{array}$ & $\begin{array}{l}0.187 \\
(0.8)\end{array}$ & $\begin{array}{l}-0.313 \\
(1.7)\end{array}$ & $\begin{array}{l}0.167 \\
(0.7)\end{array}$ \\
\hline Married & $\begin{array}{l}0.450 \\
(4.4)\end{array}$ & $\begin{array}{l}0.036 \\
(0.3)\end{array}$ & $\begin{array}{l}0.425 \\
(4.0)\end{array}$ & $\begin{array}{l}-0.132 \\
(1.0)\end{array}$ \\
\hline Local unemployment rate (\%) & $\begin{array}{l}-0.027 \\
(2.5)\end{array}$ & $\begin{array}{l}-0.029 \\
(2.2)\end{array}$ & $\begin{array}{l}0.026 \\
(2.0)\end{array}$ & $\begin{array}{l}0.028 \\
(1.4)\end{array}$ \\
\hline Expected Social Benefit (SB) & & & $\begin{array}{l}-0.144 \\
(6.9)\end{array}$ & $\begin{array}{l}-0.157 \\
(6.7)\end{array}$ \\
\hline Predicted wage & & & $\begin{array}{l}0.172 \\
(3.6)\end{array}$ & $\begin{array}{l}0.175 \\
(2.1)\end{array}$ \\
\hline Other household income & & & $\begin{array}{l}0.003 \\
(0.7)\end{array}$ & $\begin{array}{l}0.001 \\
(0.1)\end{array}$ \\
\hline Log-likelihood & -2539.40 & -2099.31 & -2502.78 & -2066.01 \\
\hline Number of spells & 2195 & 2050 & 2195 & 2050 \\
\hline Number of job exits & 517 & 407 & 517 & 407 \\
\hline
\end{tabular}

Notes: The likelihood is conditioned on survival past the first week after exhausting UI. Tstatistics are given in parenthesis. Expected SB, the predicted wage and other household income are in thousands of forints per month. Expected SB varies with duration in the manner described in the text. All models include weekly dummy variables for the base-line hazard. 


\section{FIGURES}

Figure 1: Monthly outflow rates and re-employment rates from the

Unemployment Insurance Register in Hungary (quarterly averages)

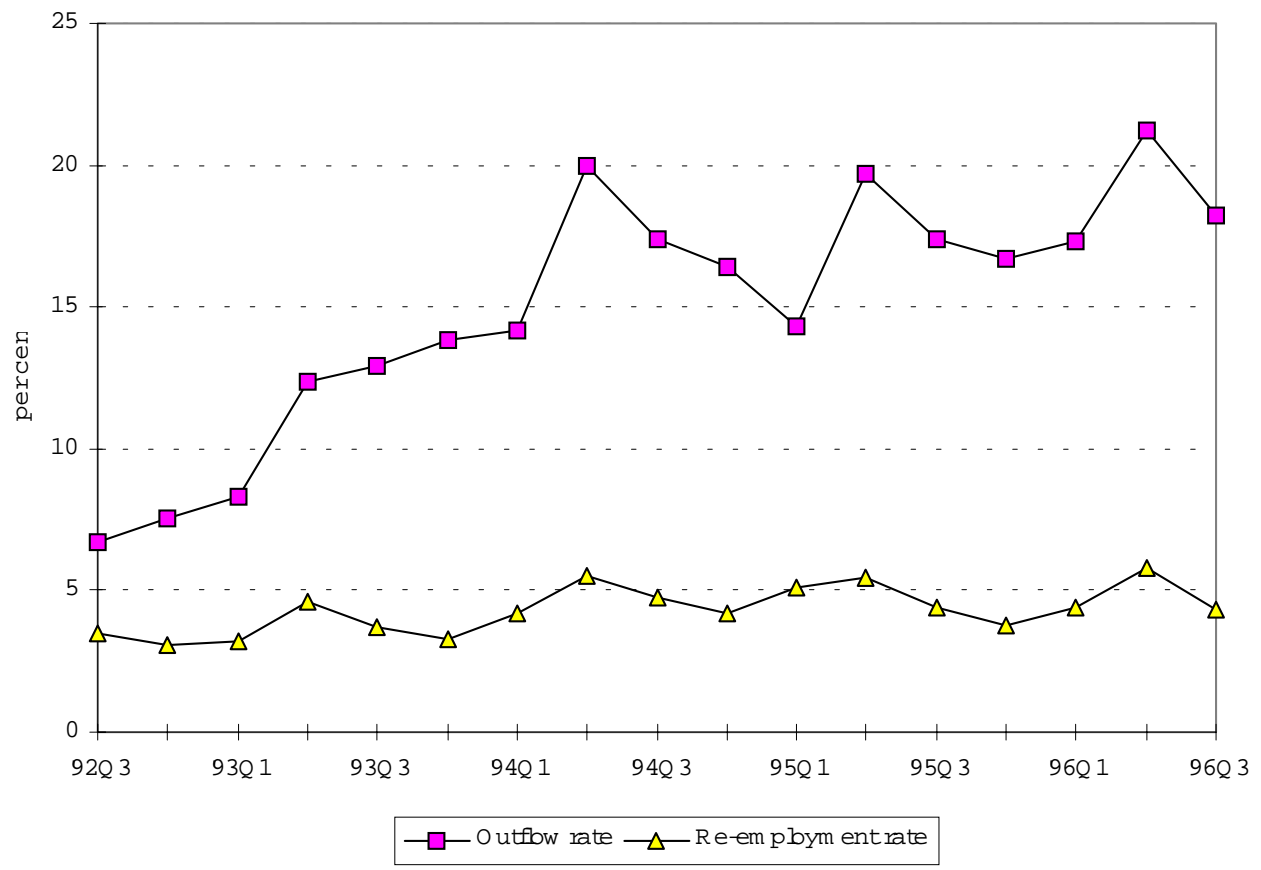

Source: National Labour Centre

Note: Outflow rates are calculated as percentage of stock of benefit recipients

a) leaving for any reason including UI exhaustion b) leaving to a job 
Figure 2: Survivor functions for claimants with 360 and 330 days entitlement period

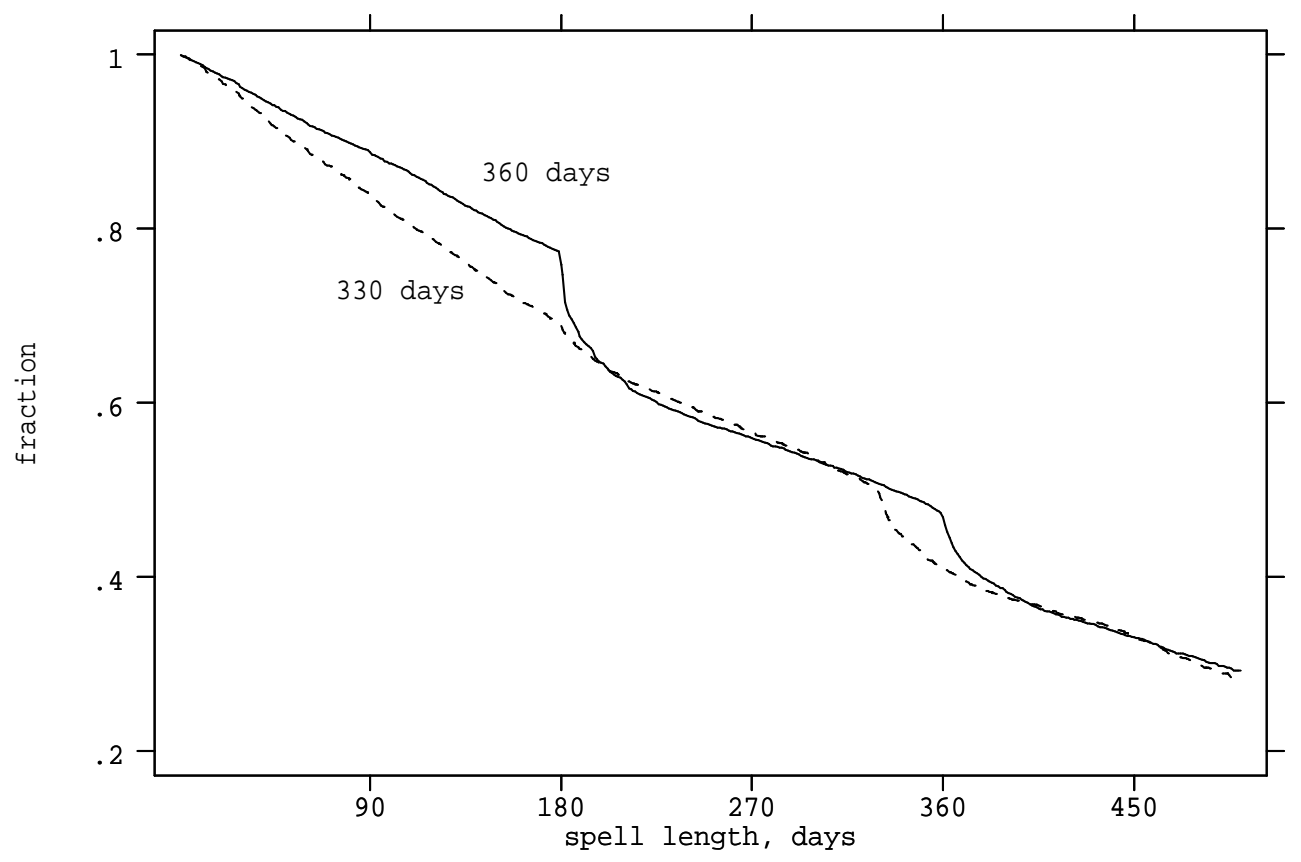


Figure 3: Estimated impacts of per capita household income and local unemployment rate on the probability of claim and award (men)
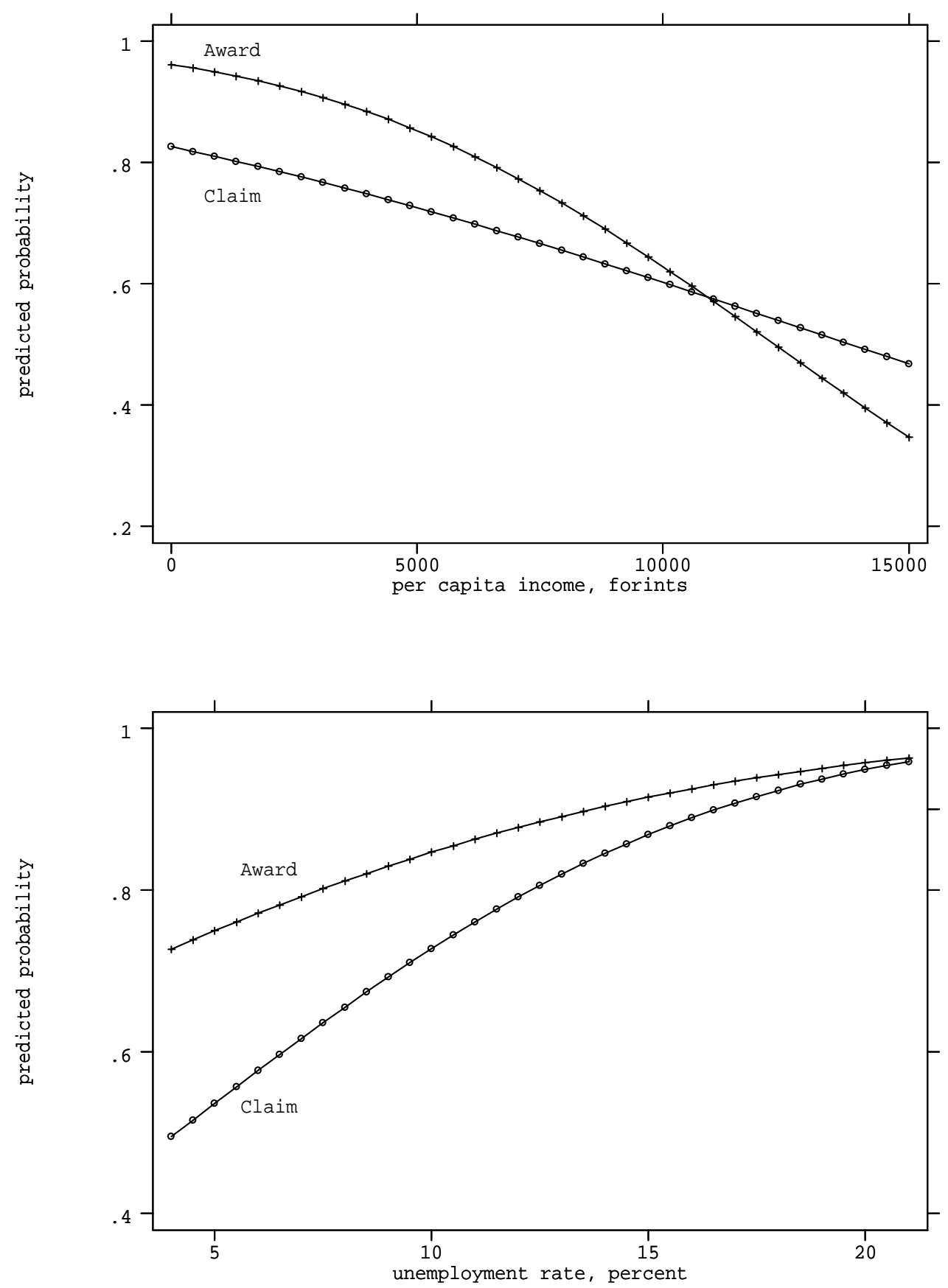

Note: Based on results in Table 5 for individuals with assumed characteristics: primary school education, single, with continuous variables set at their average values. 
Figure 4: Pre- and post exhaustion re-employment hazards by the predicted probability of SB receipt

a) Men

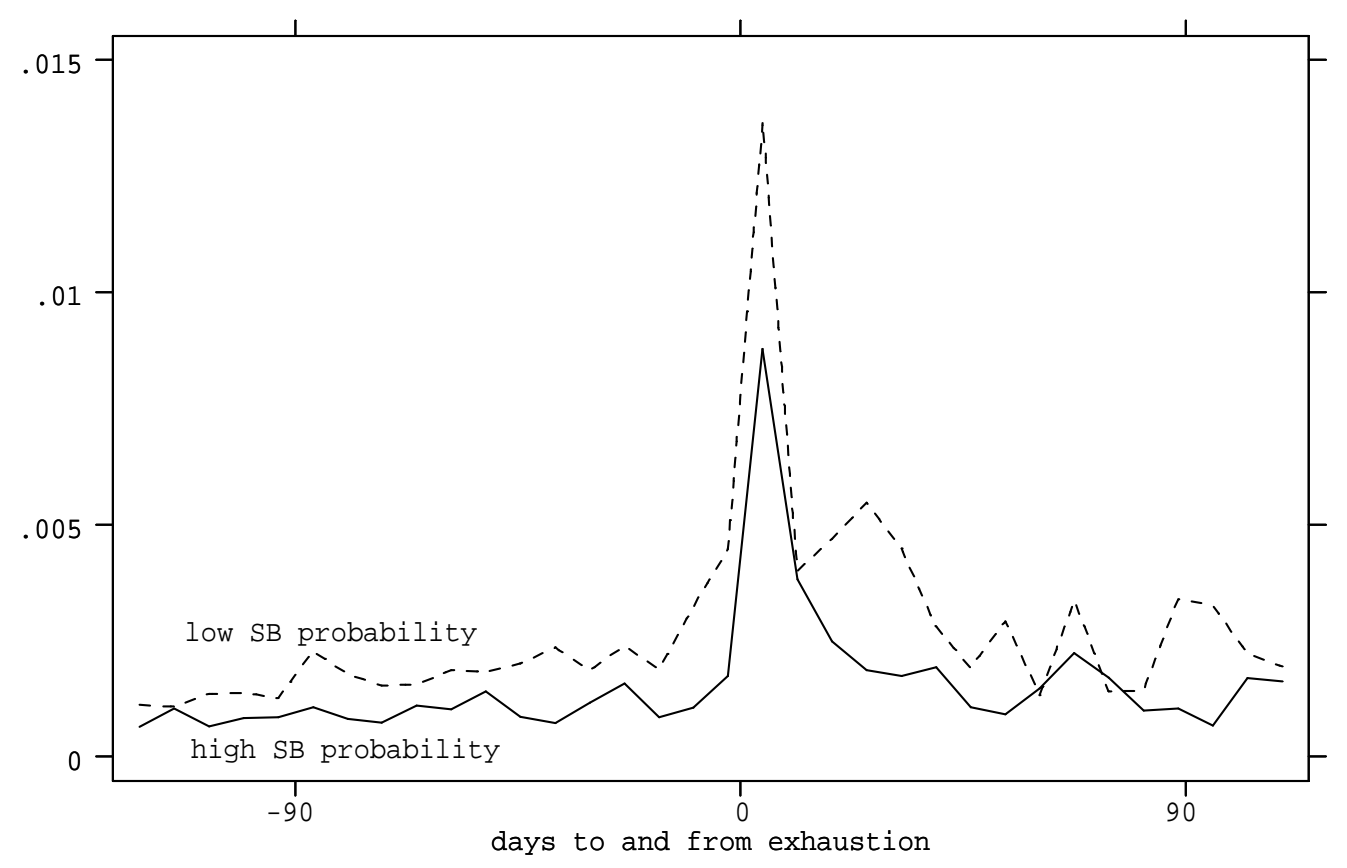

b) Women

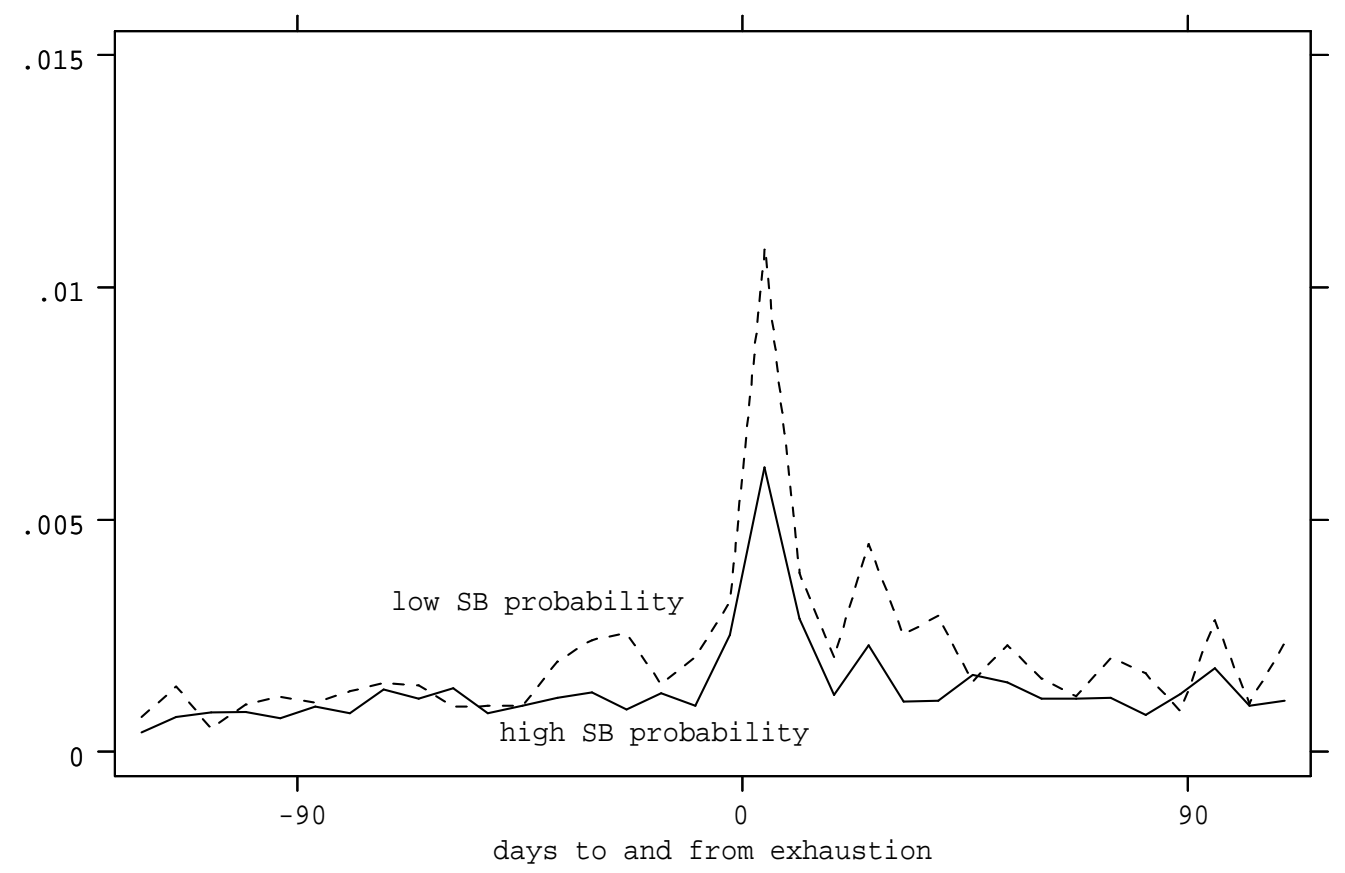

Note: High and low SB probabilities refer to the top and bottom thirds of the distributions predicted by probits of receipt estimated for the sub-sample described in the text using variables from the UI register only (pre-unemployment earnings, age, educational level, local unemployment rate, population of local council area, per capita taxable personal income in local council area). 